\title{
Rapid Statistical Optimization of Cultural Conditions for Mass Production of Carboxymethylcellulase by a Newly Isolated Marine Bacterium, Bacillus velezensis A-68 from Rice Hulls
}

\author{
Bo-Kyung Kim ${ }^{1}$, Hye-Jin Kim² and Jin-Woo Lee ${ }^{2}$. \\ ${ }^{1}$ Korea Bio-Solution Co., Busan 612-020, Korea \\ ${ }^{2}$ Department of Biotechnology, Dong-A University, Busan 604-714, Korea
}

Received March 15, 2013 /Revised May 25, 2013 /Accepted May 28, 2013

\begin{abstract}
A microorganism producing carboxymethylcellulase (CMCase) was isolated from seawater, identified as Bacillus velezensis by analyses of $16 \mathrm{~S} \mathrm{rDNA}$ and partial sequences of the gyrA, and designated as B. velezensis A-68. The optimal conditions for production of CMCase by B. velezensis A-68 were established using response surface methodology (RSM). The optimal concentrations of rice hulls and yeast extract, and initial $\mathrm{pH}$ of the medium for cell growth were $60.2 \mathrm{~g} / \mathrm{l}, 7.38 \mathrm{~g} / \mathrm{l}$, and 7.18, respectively, whereas those for production of CMCase were $50.0 \mathrm{~g} / 1,5.00 \mathrm{~g} / \mathrm{l}$, and 7.30. The analysis of variance (ANOVA) implied that the most significant factor for cell growth as well as production of CMCase was yeast extract. The optimal concentrations of $\mathrm{K}_{2} \mathrm{HPO}_{4}, \mathrm{NaCl}, \mathrm{MgSO}_{4} \cdot 7 \mathrm{H}_{2} \mathrm{O}$, and $\left(\mathrm{NH}_{4}\right)_{2} \mathrm{SO}_{4}$ in the medium for cell growth were 7.50,1.00, 0.10 , and $0.80 \mathrm{~g} / \mathrm{l}$, respectively, which were the same as those for production of CMCase. The optimal temperatures for cell growth and production of CMCase were 30 and $35^{\circ} \mathrm{C}$, respectively. The maximal production of CMCase under optimized conditions was 83.8 $\mathrm{U} / \mathrm{ml}$, which was 3.3 times higher than that before optimization. In this study, rice hulls, agro-byproduct, were developed as a substrate for production of CMCase and time for production of CMCase was reduced to 3 days using a newly isolated marine bacterium.
\end{abstract}

Key words : Bacillus velezensis, carboxymethylcellulase, marine bacterium, response surface methodology, rice hulls

\section{Introduction}

Conversion of lignocellulosic biomass to fermentable sugars represents a major challenge in global efforts to utilize renewable resources [1]. The world rice production in 2010 reaches at 464 million tone (696 million tons paddy) [24]. The annual waste product from the rice milling industry in the Republic of Korea is about 900 thousand tons of rice hulls. Hydrolysates of rice hulls contain mainly glucose and xylose, which can be used as substrates for the production of ethanol $[27,33]$. However, rice hulls are mostly disposed of in land-fill sites or burned in rice fields, and have become a significant problem to the ecology and environment due to constraints such as their low digestibility, peculiar size, low bulk density, high ash contents, and abrasive character-

\footnotetext{
*Corresponding author

Tel : +82-51-200-7593, Fax : +82-51-200-7505

E-mail : jwlee@dau.ac.kr

This is an Open-Access article distributed under the terms of the Creative Commons Attribution Non-Commercial License (http://creativecommons.org/licenses/by-nc/3.0) which permits unrestricted non-commercial use, distribution, and reproduction in any medium, provided the original work is properly cited.
}

istics [29].

Production of ethanol from lignocellulosic biomass by simultaneous saccharification and fermentation (SSF) was first reported in 1977 [31]. Enzymatic saccharification of cellulosic materials could be accomplished through a complex reaction of three different types of cellulases; endoglucanase (carboxymethylcellulase), exocellobiohydrolase (avicelase), and $\beta$ -glucosidase [4]. Rice hulls were hydrolyzed by commercial cellulases, in which the major cellulase was carboxymethylcellulase [33]. Higher exogenously added cellulases result in increased yield of SSF process [25]. A major constrain in enzymatic saccharification of cellulosic materials is the cost of cellulases and low productivity [29].

Most commercial cellulases are produced by solid state fermentations of fungal species [7]. Productions of cellulases by bacterial systems of Acetivibrio, Bacillus, Bacteriodes, Cellomonas, Clostridium, Erwinia, Thermonospora, and Ruminococcus species have been reported [26]. Enzymes produced by marine microorganisms can provide numerous advantages over traditional enzymes due to their severe living condition and wide ranges of environment [14, 15]. Hyperthermophilic bacteria isolated from marine sediments 
and seawater can utilize glucans as well as hemicellulose such as xylans and mannans [1]. Cold-adapted amylase and arginine kinase were produced by marine bacteria $[23,30]$.

In this study, a microorganism producing carboxymethylcellulase (CMCase) was isolated from seawater and identified as Bacillus velezensis. The optimal conditions for the production of CMCase by $B$. velezensis using rice hulls were established using response surface methodology (RSM) $[17,22]$.

\section{Materials and Methods}

Isolation of a marine microorganism producing
carboxymethylcellulase
To isolate microorganism producing carboxymethylcellulase
(CMCase), seawater from Kyungsang Province of Korea was diluted with $0.85 \%(\mathrm{w} / \mathrm{v}) \mathrm{NaCl}$. The suspension was then cultivated on the marine agar plate (Difco Marine Agar 2216, Difco Lab., Franklin, USA) at $30^{\circ} \mathrm{C}$ for 3 days under aerobic conditions. Starter cultures of isolated microorganisms were prepared by transferring cells from the agar plate to $200 \mathrm{ml}$ of the medium in $500 \mathrm{ml}$ Erlenmeyer flasks. The medium used for production of CMCase contained the following components: $20.0 \mathrm{~g} / 1$ carboxymethylcellulose (CMC), $2.5 \mathrm{~g} / 1$ yeast extract, $5.0 \mathrm{~g} / 1 \mathrm{~K}_{2} \mathrm{HPO}_{4}, 1.0 \mathrm{~g} / 1 \mathrm{NaCl}, 0.2 \mathrm{~g} / 1$ $\mathrm{MgSO}_{4} \cdot 7 \mathrm{H}_{2} \mathrm{O}$, and $0.6 \mathrm{~g} / 1\left(\mathrm{NH}_{4}\right)_{2} \mathrm{SO}_{4}$, which had been previously optimized $[15,16]$. The resulting cultures were incubated at $30^{\circ} \mathrm{C}$ for 3 days under aerobic conditions. After the cultivation, cells were removed from the culture broth by centrifugation at $12,000 \times g$ for $20 \mathrm{~min}$ and the supernatants were dialyzed overnight against distilled water. Based on productivity of CMCase, one microorganism was selected for production of CMCase and identified by sequencing of $16 \mathrm{~S}$ rDNA and gyres A gene (gyrA).

\section{Analyses of 16S rDNA and gyrase A gene sequences}

For sequence analysis, bacterial genomic DNA was extracted and purified using a Wizard Genomic DNA Prep. Kit (Promega Co., Madison, USA). Two primers annealing at the $5^{\prime}$ and $3^{\prime}$ end of the $16 \mathrm{~S}$ rDNA were $5^{\prime}$-AGGAGG AAAAGATCAGATATGAAACGGTCAATC- $3^{\prime}$ and $5^{\prime}$-TCCA GTATTTCATCCACAACGACCTCC-3', respectively. The gyrA region was amplified using two oligonucleotide primers, $5^{\prime}$-CAGTCAGGAAATGCGTACGTCCTT- $3^{\prime}$ and $5^{\prime}$ CAAGGTAATGCTCCAGGCATT GCT-3' [3]. PCR amplifi- cation was performed as described in the previous report [12]. The PCR was run for 35 cycles in a DNA thermal cycler (Model No. 9700, Perkin-Elmer Co. Wellesley, USA). Amplified PCR products were then analyzed in a 1.0\% $(\mathrm{w} / \mathrm{v})$ agarose gel, excised from the gel, and purified. Purified products were cloned into a pGEM-T Easy vector (Promega Co., Madison, USA) and subsequently sequenced using an ALF Red automated DNA sequencer (Pharmacia, Sweden). The $16 \mathrm{~S}$ rDNA sequence of the isolate was aligned with those in the GenBank database. Multiple alignments of sequences and calculations of levels of sequence similarity were performed by using CLUSTAL W [32]. Neighbor-joining phylogenetic analysis was carried out with a MEGA program [18].

\section{Production of carboxymethylcellulase by isolated microorganism}

The main culture for production of CMCase was carried out in the medium containing $20.0 \mathrm{~g} / 1 \mathrm{CMC}, 2.5 \mathrm{~g} / 1$ yeast extract, $5.0 \mathrm{~g} / 1 \mathrm{~K}_{2} \mathrm{HPO}_{4}, 1.0 \mathrm{~g} / 1 \mathrm{NaCl}, 0.2 \mathrm{~g} / 1 \mathrm{MgSO}_{4} \cdot 7 \mathrm{H}_{2} \mathrm{O}$, and $0.6 \mathrm{~g} / 1\left(\mathrm{NH}_{4}\right)_{2} \mathrm{SO}_{4}$ for 3 days under aerobic conditions. Batch fermentations for production of CMCase by an isolated microorganism were performed in a 1001 bioreactor (Ko-Biotech Co., Korea). Working volumes of 1001 bioreactors were 701 and inoculum sizes of batch were 5\% $(\mathrm{v} / \mathrm{v})$. Agitation was provided by three six-flat-blade impellers. Samples were periodically withdrawn from the cultures to examine cell growth and production of CMCase.

\section{Experimental design using response surface methodology}

The rice hulls $\left(X_{1}\right)$, yeast extract $\left(X_{2}\right)$, and initial $\mathrm{pH}$ of the medium $\left(X_{3}\right)$ were chosen as the independent variables and cell growth $\left(Y_{1}\right)$ and CMCase $\left(Y_{2}\right)$ were used as a dependent output variable. The model constructed as a response function of the variables on cell growth and production of CMCase was a second-order polynomial as follows (Eq. 1):

$$
Y=\beta_{0}+\sum \beta_{i} X_{i}+\sum \beta_{i i} X_{i}^{2}+\sum \beta_{i j} X_{i} X_{j}
$$

Where, $y$ is the measured response (cell growth as measured dry cells weight or production of CMCase), $\beta_{0}, \beta_{i j}$, and $\beta_{i j}$ are the regression coefficients, and $X_{i}$ and $X_{j}$ are the factors under study. For three variable systems, the model equation is given below (Eq. 2). Regression analysis and esti- 
mation of the coefficient were performed using the statistical software, Design-Expert (Version 7.1.6, Stat-Ease Inc., Minneapolis, USA). The contribution of individual parameters and their quadratic and interactive effects on cell growth and production of CMCase were determined.

$$
\begin{aligned}
Y= & \beta_{0}+\beta_{1} X_{1}+\beta_{2} X_{2}+\beta_{3} X_{3}+\beta_{11} X_{1}^{2}+\beta_{22} X_{2}^{2}+\beta_{33} X_{3}^{2}+\beta_{12} X_{1} X_{2}+\beta_{13} X_{1} \\
& X_{3}+\beta_{23} X_{2} X_{3}
\end{aligned}
$$

The $\mathrm{K}_{2} \mathrm{HPO}_{4}\left(X_{1}\right), \mathrm{NaCl}\left(X_{2}\right), \mathrm{MgSO}_{4} \cdot 7 \mathrm{H}_{2} \mathrm{O}\left(X_{3}\right)$, and $\left(\mathrm{NH}_{4}\right)_{2} \mathrm{SO}_{4}\left(\mathrm{X}_{4}\right)$ were also chosen as the independent variables, and each variable was designated as $-1,0$, and 1 , respectively. Cell growth $\left(\mathrm{Y}_{1}^{\prime}\right)$ and CMCase $\left(\mathrm{Y}_{2}^{\prime}\right)$ were used as dependent output variables. For four variable systems, the model equation is given below (Eq. 3).

$$
\begin{aligned}
y= & \beta_{0}+\beta_{1} X_{1}+\beta_{2} X_{2}+\beta_{3} X_{3}+\beta_{4} X_{4}+\beta_{11} X_{1}^{2}+\beta_{22} X_{2}^{2}+\beta_{33} X_{3}^{2}+\beta_{44} X_{4}^{2} \\
& +\beta_{12} X_{1} X_{2}+\beta_{13} X_{1} X_{3}+\beta_{14} X_{1} X_{4}+\beta_{23} X_{2} X_{3}+\beta_{24} X_{2} X_{4}+\beta_{34} X_{3} X_{4}(3)
\end{aligned}
$$

\section{Analytic Methods}

Cell growth as the dry cells weight, was measured by directly weighing the biomass after drying to a constant weight at $100-105^{\circ} \mathrm{C}$ after collection of cells by centrifugation at $12,000 \times g$ for $10 \mathrm{~min}$. The activity of CMCase was measured by the 3,5-dinitrosalicylic acid (DNS) method [9], through the determination of the amount of reducing sugars liberated from CMC solubilized in $50 \mathrm{mM}$ Tris- $\mathrm{HCl}$ buffer, $\mathrm{pH}$ 8.0. The cellulase activity was determined by using a calibration curve for glucose (Sigma-Aldrich, UK). One unit of enzyme activity was defined as the amount of enzyme that released $1 \mu \mathrm{mol}$ of glucose for $1 \mathrm{~min}$.

\section{Results and Discussion}

\section{Identification of isolated microorganism}

A microorganism producing CMCase isolated from seawater from Kyungsang Province in Korea was designated as strain A-68. The phylogenetic analysis of the strain A-53 using its $16 \mathrm{~S}$ rDNA nucleotide sequence data showed that this strain had the highest homology (99.77\%) with Bacillus velezensis LMG 22478T, as shown in Table 1 . The partial sequences of the gyr A gene of strain A-53 also showed the highest homology $(99.77 \%)$ with B. velezensis LMG 22478T. Based on the evolution distance and the phylogenetic tree resulting from partial sequencing of the gyr A gene and the neighbour-joining method $[2,3]$, this strain was identified as a Bacillus velezensis and designated as B. velezensis A-68, as shown in Fig. 1.

\section{Effect of carbon and nitrogen sources on production of CMCase}

The effect of carbon and nitrogen sources on cell growth and the production of CMCase by $B$. velezensis A- 68 was investigated. Carbon sources used in this study were 20.0 $\mathrm{g} / 1$ glucose, fructose, maltose, sucrose, rice bran, and rice hulls. Nitrogen sources were $2.5 \mathrm{~g} / 1$ malt extract, peptone, tryptone, yeast extract, ammonium sulfate, and ammonium nitrate. Rice hulls used in this study consisted of $47.0 \%$ fiber, $0.2 \%$ crude lipid, $2.4 \%$ crude protein, $14.1 \%$ ash, and $7.1 \%$ water [9]. Maltose and yeast extract were found to be the best combination of carbon and nitrogen sources for cell

Table 1. Similarity of the isolated microorganism with Bacillus species based on the 16S rDNA sequences

\begin{tabular}{lcc}
\hline \multicolumn{1}{c}{ Strain } & Similarity $(\%)$ & Nucleotide differences/compared \\
\hline Bacillus velezensis LMG 22478T & 99.77 & $2 / 871$ \\
Bacillus amyloliquefaciens ATCC 23350T & 99.65 & $3 / 865$ \\
Bacillus atrophaeus JCM 9070T & 99.54 & $4 / 874$ \\
Bacillus vallismortis DSM 1103T & 99.43 & $5 / 874$ \\
Bacillus subtilis subsp. subtilis NCDO 1769T & 99.31 & $6 / 870$ \\
Bacillus majavensis IFO 15718T & 99.08 & $8 / 874$ \\
Bacillus subtilis subsp. subtilis DSM 10T & 99.08 & $8 / 873$ \\
Bacillus licheniformis DSM 13T & 97.59 & $21 / 873$ \\
Bacillus pumilus NCDO 1766T & 96.47 & $30 / 850$ \\
Bacillus carboniphilus JCM 973T & 95.06 & $43 / 870$ \\
Bacillus oleronius DSM 9356T & 94.68 & $46 / 865$ \\
Bacillus sporothermodurans DSM 10599T & 94.59 & $47 / 868$ \\
Bacillus indicus Sd/3T & 94.54 & $47 / 861$ \\
Bacillus firmus IAM 12464 & 94.23 & $50 / 866$ \\
Bacillus methanolicus NCIMB 13114T & 94.15 & $51 / 872$ \\
Bacillus azotoformans ATCC 29788T & 93.98 & $50 / 830$ \\
\hline
\end{tabular}




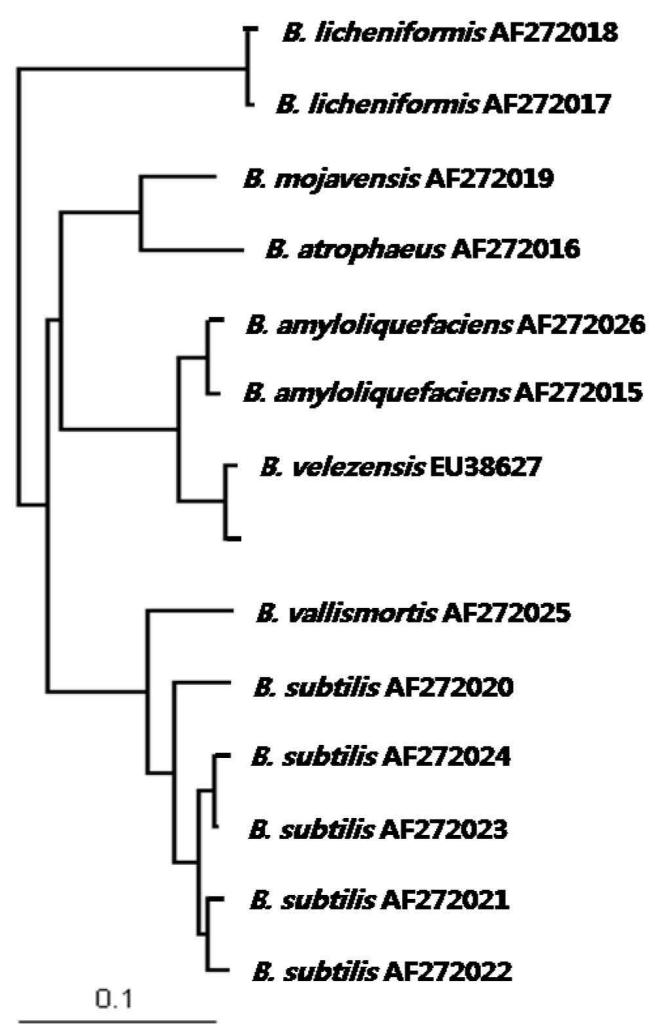

Fig. 1. Neighbour-joining tree based on gyrase A gene sequences of Bacillus subtilis complex. Scale bar indicates 0.1 nucleotide substitution per nucleotide position.

growth of $B$. velezensis A-68, whereas rice hulls and yeast extract were the best one for production of CMCase, as shown in Fig. 2. The best combination of carbon and nitrogen sources for cell growth of $B$. velezensis A-68 was different from that for the production of CMCase. The highest production of CMCase by $B$. velezensis A- 68 was $25.3 \mathrm{U} / \mathrm{ml}$ from $20.0 \mathrm{~g} / 1$ rice hulls and $2.5 \mathrm{~g} / 1$ yeast extract.

The best combination of carbon and nitrogen sources for the production of CMCase by B. amyloliquefaciens DL-3 was rice hulls and peptone and that by $B$. licheniformis LBH-52 was rice hulls and ammonium nitrate $[9,16]$, whereas that for the production of CMCase by a marine bacterium, $B$. sutilis subsp. sutilis A-53 was rice bran and yeast extract [12, 19]. The best carbon and nitrogen source for the production of CMCase by a psychrophilic marine bacterium, Psychrobacter aquimaris LBH-10 were reported to be rice bran and peptone [15]. Wheat bran has been reported to be a major carbon source for the production of CMCases by Aspergillus and Trichoderma [11]. All strains investigated to date for the production of cellulases are inducible by cellulose, lactose or sophorose, and all are repressible by glucose,
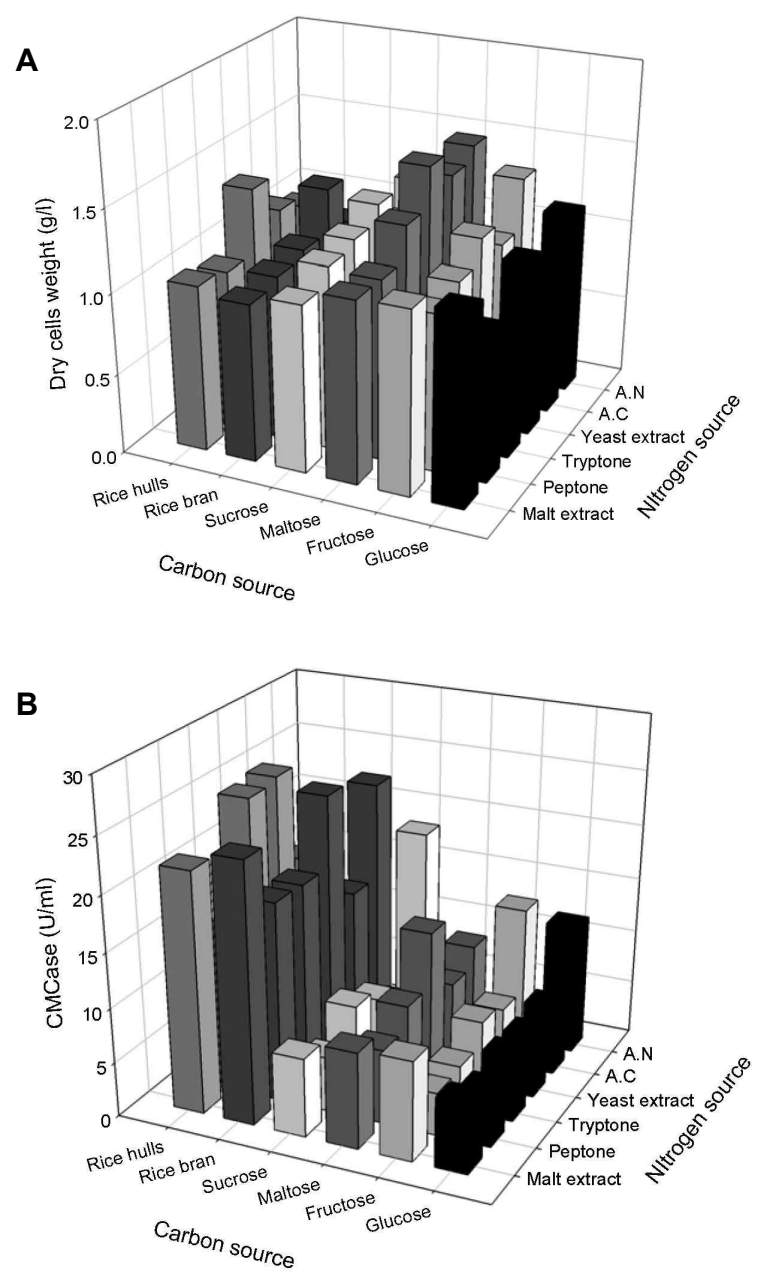

Fig. 2. Effect of carbon and nitrogen sources on cell growth (A) and production of CMCase (B) by B. velezensis A-68.

which are reasons why most carbon sources for the production of CMCase are rice hulls, rice bran or wheat bran [11]. Induction, synthesis, and secretion of the $\beta$-glucanase appear to be closely associated [4].

Optimization of rice hulls, yeast extract, and initial $\mathrm{pH}$ for production of CMCase

The optimal conditions of rice hulls, yeast extract, and initial $\mathrm{pH}$ of the medium for cell growth and the production of CMCase by $B$. velezensis A-68 were investigated using one-factor-at-a-time experiment. Composition of basic medium and culture conditions were $50.0 \mathrm{~g} / 1$ rice hulls, 5.0 $\mathrm{g} / 1$ yeast extract, and initial $\mathrm{pH}$ of 7.3 , as shown in Fig. 3 . The optimal concentrations of rice hulls and initial $\mathrm{pH}$ of the medium for cell growth as well as production of CMCase by $B$. velezensis A-68 were $50.0 \mathrm{~g} / 1$ and 7.3 , respectively. The optimal concentration of yeast extract for cell growth was 


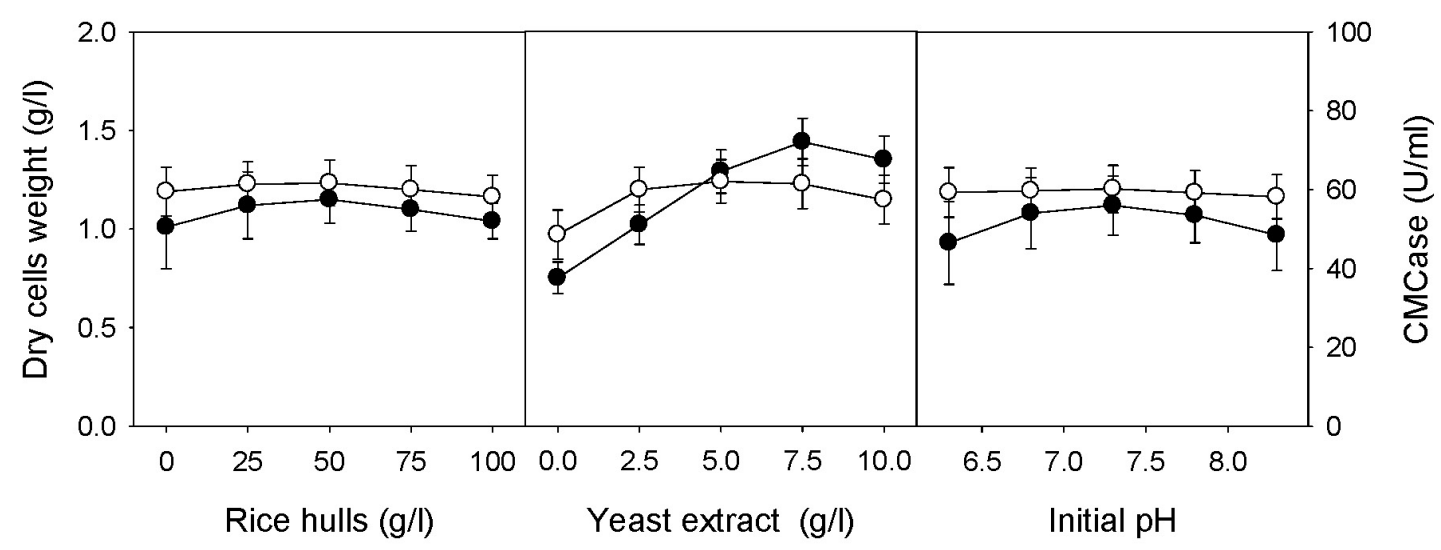

Fig. 3. Effect of rice hulls, yeast extract, and initial $\mathrm{pH}$ of medium cell growth and production of CMCase by B. velezensis A-68.

O, DCW and $\bigcirc$, CMCase

Table 2. Central composite design (CCD) and determined response values for optimization of rice hulls, yeast extract, and initial $\mathrm{pH}$ of medium

\begin{tabular}{cccccc}
\hline Run & $X_{1}(\mathrm{~g} / \mathrm{l})$ & $\mathrm{X}_{2}(\mathrm{~g} / \mathrm{l})$ & $\mathrm{X}_{3}$ & $\mathrm{Y}_{1}(\mathrm{~g} / \mathrm{l})$ & $\mathrm{Y}_{2}(\mathrm{U} / \mathrm{ml})$ \\
\hline 1 & 50 & 5.0 & 7.3 & 1.19 & 61.3 \\
2 & 50 & 5.0 & 7.3 & 1.22 & 61.7 \\
3 & 50 & 5.0 & 6.5 & 1.14 & 61.1 \\
4 & 75 & 2.5 & 7.8 & 1.06 & 59.7 \\
5 & 92 & 5.0 & 7.3 & 1.14 & 60.3 \\
6 & 25 & 2.5 & 6.8 & 1.07 & 60.2 \\
7 & 50 & 5.0 & 7.3 & 1.20 & 60.8 \\
8 & 50 & 5.0 & 7.3 & 1.21 & 61.5 \\
9 & 50 & 9.2 & 1.32 & 59.3 \\
10 & 75 & 2.5 & 6.8 & 1.07 & 59.5 \\
11 & 50 & 5.0 & 8.1 & 1.15 & 60.8 \\
12 & 50 & 7.3 & 1.03 & 58.2 \\
13 & 25 & 0.8 & 6.8 & 1.21 & 60.8 \\
14 & 75 & 7.5 & 7.8 & 1.20 & 60.2 \\
15 & 8 & 7.5 & 7.3 & 1.13 & 60.8 \\
16 & 25 & 5.0 & 7.8 & 1.21 & 60.7 \\
17 & 75 & 7.5 & 6.8 & 1.21 & 60.4 \\
18 & 50 & 7.5 & 7.3 & 1.18 & 61.2 \\
19 & 50 & 5.0 & 7.3 & 1.21 & 61.4 \\
20 & 25 & 5.0 & 7.8 & 1.07 & 60.2 \\
\hline
\end{tabular}

$7.5 \mathrm{~g} / \mathrm{l}$, whereas that for production of CMCase was $5.0 \mathrm{~g} / \mathrm{l}$.

Based on results from one-factor-at-a-time experiment, the optimal conditions of rice bran, yeast extract, and initial $\mathrm{pH}$ of the medium on cell growth and production of CMCase was also investigated using response surface methodology. The coded values of minimum and maximum ranges of rice hulls $\left(X_{1}\right)$, yeast extract $\left(X_{2}\right)$, and initial $\mathrm{pH}$ of the medium $\left(X_{3}\right)$ were 25.0 and $75.0 \mathrm{~g} / 1,2.5$ and $7.5 \mathrm{~g} / \mathrm{l}$, and 6.8 and 7.8, respectively. Cell mass, measured as dry cells weight (DCW), and production of CMCase from 20 different conditions ranged from 1.03 to $1.22 \mathrm{~g} / 1$ and from 58.2 to 61.7
$\mathrm{U} / \mathrm{ml}$, as shown in Table 2. The model $F$-value of 41.10 from the analysis of variance (ANOVA) of cell growth implied that this model was significant, as shown in Table 3. The $P$ values were used as a tool to check the significance of each of the coefficients, which, in turn were necessary to understand the pattern of the mutual interactions between the test variables. The smaller the magnitude of the $P$ value, the more significant is the corresponding coefficient. The ANOVA indicated that this model and the model terms of $\mathrm{X}_{2}$ and $\mathrm{X}_{2}^{2}$ ("probe $>\mathrm{F}^{\prime \prime}$ less 0.001 ) were highly significant and those of $X_{1}^{2}$ and $X_{3}^{2}$ ("probe $>F^{\prime \prime}$ less 0.050) were sig- 
Table 3. Parameter estimates and analysis of variance (ANOVA) of the design for optimization of rice hulls, yeast extract, and initial $\mathrm{pH}$ for cell growth and production of CMCase by B. velezensis A-68

\begin{tabular}{ccccccc}
\hline & Source of variation & Degree of freedom & Sum of squares & Mean squares & $F$-value & Probe $>$ F \\
\hline & Model & 9 & 0.075 & 0.008 & 41.10 & $<0.001$ \\
& $X_{1}$ & 1 & 0.000 & 0.000 & 0.00 & 0.953 \\
Cell & $\mathrm{X}_{2}$ & 1 & 0.057 & 0.057 & 279.91 & $<0.001$ \\
growth & $\mathrm{X}_{3}$ & 1 & 0.000 & 0.000 & 0.00 & 0.953 \\
& $\mathrm{X}_{1}^{2}$ & 1 & 0.007 & 0.007 & 35.06 & 0.001 \\
& $\mathrm{X}_{2}^{2}$ & 1 & 0.010 & 0.010 & 47.13 & $<0.001$ \\
& $\mathrm{X}_{3}^{2}$ & 1 & 0.005 & 0.005 & 24.78 & 0.001 \\
& Error & 5 & 0.001 & 0.000 & - & - \\
\hline \multirow{6}{*}{ CMCase } & 19 & 0.077 & - & - & - \\
& Total & 9 & 13.15 & 1.45 & 21.63 & $<0.001$ \\
& Model & 1 & 0.63 & 0.63 & 9.37 & 0.012 \\
& $X_{1}$ & 1 & 1.39 & 1.39 & 20.51 & 0.001 \\
& $X_{2}$ & 1 & 0.03 & 0.03 & 0.40 & 0.543 \\
& $X_{3}^{2}$ & 1 & 0.75 & 0.75 & 11.09 & 0.008 \\
& $X_{1}^{2}$ & 1 & 10.77 & 10.77 & 159.38 & $<0.001$ \\
& $X_{2}^{2}$ & 1 & 0.11 & 0.11 & 1.60 & 0.235 \\
\hline
\end{tabular}

nificant for cell growth of $B$. velezensis A-68. The regression equation obtained from ANOVA indicated that the multiple correlation coefficient of $\mathrm{R}^{2}$ was 0.974 . The model can explain $97.4 \%$ variation in the response. The value of the adjusted determination coefficient (Adj. $\mathrm{R}^{2}=0.950$ ) was very high to advocate for a high significance of this model [22]. The predicted determination of coefficient of 0.887 was in reasonable agreement with the Adj. $\mathrm{R}^{2}$ of 0.950 . From the statistical results obtained, it was shown that the above models were adequate to predict the cell growth of $B$. velezensis A-68 within the range of variables studied. Multiple regression analysis of the experimental data gave the following second-order polynomial equation in terms of coded factors (Eq. 4). The optimal conditions of rice hulls, yeast extract, and initial $\mathrm{pH}$ of the medium for cell growth extracted by Design Expert Software were $60.2 \mathrm{~g} / 1,7.38 \mathrm{~g} / \mathrm{l}$, and 7.18, respectively. The maximum cell growth of $1.23 \mathrm{~g} / 1$ was predicted by this model. The maximal actual value of cell growth was 1.22 $\mathrm{g} / 1$ when concentrations of rice hulls and yeast extract and initial pH of medium were $50.0 \mathrm{~g} / 1,5.0 \mathrm{~g} / \mathrm{l}$, and 7.3.

$$
Y_{1}=1.20+0.06 X_{2}-0.02 X_{1}^{2}+0.03 X_{2}^{2}-0.03 X_{3}^{2}
$$

The model $F$-value of 21.63 from the ANOVA of production of CMCase implied that this model was also significant. The ANOVA indicated that this model and model terms of $X_{2}^{2}$ were highly significant and those of $X_{1}, X_{2}$, and $X_{2}^{2}$ were significant for the production of CMCase by
B. velezensis A-68. The regression equation obtained from ANOVA indicated that the multiple correlation coefficient of $\mathrm{R}^{2}$ was 0.951 . The value of the adjusted determination coefficient (Adj. $R^{2}=0.907$ ) was high to advocate for a high significance of this model. From the statistical results obtained, it was shown that the above models were adequate to predict the production of CMCase by B. velezensis A-68 within the range of variables studied. Multiple regression analysis of the experimental data gave the following second-order polynomial equation in terms of coded factors (Eq. 5). The optimal conditions of rice hulls, yeast extract, and initial $\mathrm{pH}$ of the medium for production of CMCase were $50.0 \mathrm{~g} / \mathrm{l}, 5.00 \mathrm{~g} / \mathrm{l}$, and 7.30, respectively. The maximum production of CMCase of $61.3 \mathrm{U} / \mathrm{ml}$ was predicted by this model. The maximal actual value of CMCase production was $61.7 \mathrm{U} / \mathrm{ml}$ when concentrations of rice hulls and yeast extract and initial $\mathrm{pH}$ of medium were $50.0 \mathrm{~g} / 1,5.0 \mathrm{~g} / \mathrm{l}$, and 7.3.

$$
\begin{aligned}
Y_{2} & =61.31-0.22 X_{1}+0.32 X_{2}-0.04 X_{3}+0.04 X_{1} X_{2}+0.10 X_{1} X_{3} \\
& -0.06 X_{2} X_{3}-0.236 X_{1}^{2}-0.86 X_{2} 2+0.09 X_{3}^{2}
\end{aligned}
$$

The three-dimensional response surface plots were generated to investigate their combined effects of rice hulls and yeast extract, rice hulls and initial $\mathrm{pH}$, and yeast extract and initial $\mathrm{pH}$ on the response of cell growth and the production of CMCase by B. velezensisA-68, as shown in Fig. 4 . The $\mathrm{P}$-values of rice hulls and yeast extract, rice hulls and initial 

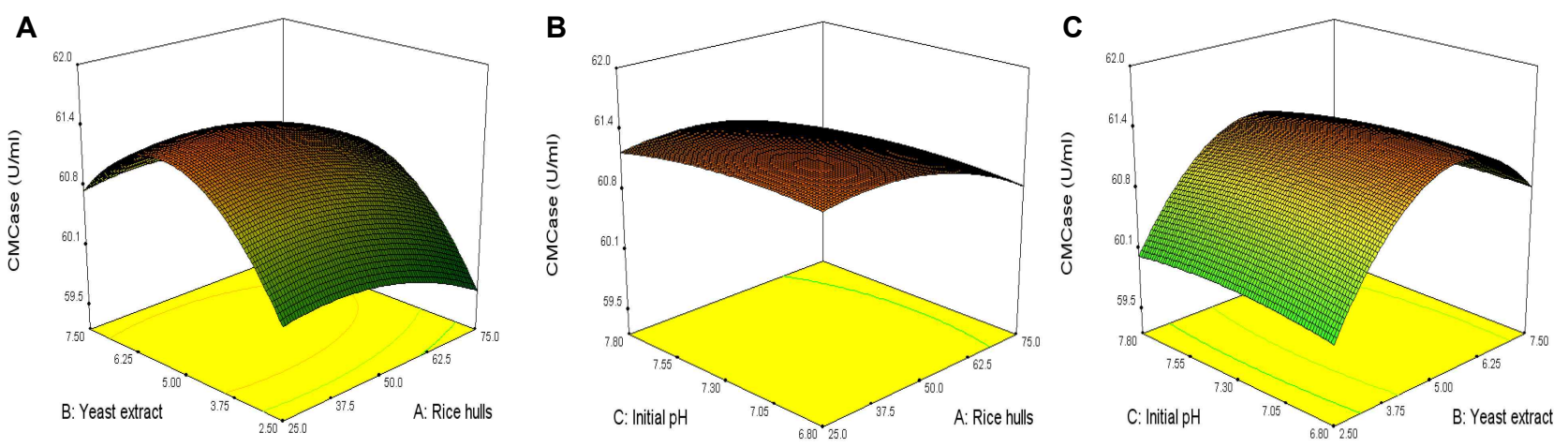

Fig. 4. 3D response surface displaying relative combined effects of rice hulls and yeast extract (A), rice hulls and initial $\mathrm{pH}(\mathrm{B})$, and yeast extract and initial $\mathrm{pH}(\mathrm{C})$ on production of CMCase by B. velezensis A-68.

$\mathrm{pH}$, and yeast extract and initial $\mathrm{pH}$ were $0.6918,0.8945$, and 0.5116 , respectively. Interactive effect of yeast extract and initial $\mathrm{pH}$ of medium on the production of CMCase by $B$. velezensisA-68 was relatively more significant than those of rice hulls and yeast extract as well as rice hulls and initial $\mathrm{pH}$.

The optimal concentrations of rice bran and yeast extract for the production of CMCase by B. sutilis subsp. sutilis A-53 were 50.0 and $1.0 \mathrm{~g} / \mathrm{l}$, respectively. However, those for its cell growth were higher than those for production of CMCase [19]. The optimal concentrations of carbon and nitrogen source for cell growth of $B$. velezensis A-68 were also different from those for production of CMCase. The optimal concentrations of rice hulls and yeast extract for the production of CMCase by B. amyloliquefaciens DL-3 were 50.0 and $2.0 \mathrm{~g} / 1$, respectively, whereas those for cell growth was 50.0 and $3.0 \mathrm{~g} / 1$ [9].The optimal initial $\mathrm{pH}$ of the medium and temperature for cell growth of $B$. amyloliquefaciens DL-3 were 7.2 and $32^{\circ} \mathrm{C}$, whereas those for the production of CMCase were 6.8 and $37^{\circ} \mathrm{C}$ [9]. The production of CMCase by another marine microorganism, B. subtilis subsp. subtilis A-53 was $136.8 \mathrm{U} / \mathrm{ml}$ when initial $\mathrm{pH}$ of the medium and temperature were 6.8 and $30^{\circ} \mathrm{C}$ [19]. The optimal initial pHs for the production of CMCases by bacterial and fungal microorganisms ranged from 4.0 to 7.3 [14]. Generally speaking, optimal initial $\mathrm{pHs}$ for the production of CMCases by bacterial strains are higher than those by fungal strains.

Optimization of salts in medium for production of CMCase

The optimal concentrations of 4 salts in the medium, $\mathrm{K}_{2} \mathrm{HPO}_{4}, \mathrm{NaCl}, \mathrm{MgSO}_{4} \cdot \pi_{2} \mathrm{O}$, and $\left(\mathrm{NH}_{4}\right)_{2} \mathrm{SO}_{4}$, for cell growth and the production of CMCase by B. velezensis A-68 were investigated using one-factor-at-a-time experiment. Concentrations of rice hulls and yeast extract and initial $\mathrm{pH}$ of the medium were $50.0 \mathrm{~g} / 1,5.0 \mathrm{~g} / \mathrm{l}$, and 7.3. Concentrations of $\mathrm{K}_{2} \mathrm{HPO}_{4}, \mathrm{NaCl}, \mathrm{MgSO}_{4} \cdot 7 \mathrm{H}_{2} \mathrm{O}$, and $\left(\mathrm{NH}_{4}\right)_{2} \mathrm{SO}_{4}$ in the basic medium were 5.0, 2.0, 0.5, and $1.0 \mathrm{~g} / \mathrm{l}$. The optimal concentrations of $\mathrm{K}_{2} \mathrm{HPO}_{4}, \mathrm{NaCl}, \mathrm{MgSO}_{4} \cdot 7 \mathrm{H}_{2} \mathrm{O}$, and $\left(\mathrm{NH}_{4}\right)_{2} \mathrm{SO}_{4}$ for cell growth 7.5, 2.0, 0.25, and $1.0 \mathrm{~g} / \mathrm{l}$, respectively, which were the same as those for production of CMCase, as shown in Fig. 5.

Based on results from one-factor-at-a-time experiment, the optimal concentrations of 4 salts in the medium on cell growth and production of CMCase were also investigated using RSM. Levels of $\mathrm{K}_{2} \mathrm{HPO}_{4}, \mathrm{NaCl}, \mathrm{MgSO}_{4} \cdot{ }_{7 \mathrm{H}} \mathrm{O}$, and $\left(\mathrm{NH}_{4}\right)_{2} \mathrm{SO}_{4}$ ranged from 2.5 to $7.5 \mathrm{~g} / \mathrm{l}$, from 1.0 to $3.0 \mathrm{~g} / \mathrm{l}$, from 0.25 to $0.75 \mathrm{~g} / \mathrm{l}$, and from 0.5 to $1.5 \mathrm{~g} / \mathrm{l}$, respectively. The results of central composite design (CCD) experiments consisted of experimental data to investigate effects of four independent variables, as shown in Table 4. Cell growth and production of CMCase from 30 different conditions ranged from 1.15 to $1.36 \mathrm{~g} / 1$ and from 71.1 to $79.0 \mathrm{U} / \mathrm{ml}$. The analysis of variance (ANOVA) of cell growth of $B$. velezensis A-68 indicated that this model and the model term of $X_{1}$ were highly significant ("probe $>F^{\prime \prime}$ less than 0.0001) and that of $\mathrm{X}_{2}^{2}$ was significant ("probe $>\mathrm{F}^{\prime \prime}$ less than 0.0500 ) for cell growth, as shown in Table 5 . The model $F$-value of 12.89 implied that this model was significant. The regression equation obtained from the ANOVA indicated that the multiple correlation coefficient of $\mathrm{R}^{2}$ was 0.9232 . The predicted determination of coefficient of 0.7626 was in reasonable agreement with the Adj. $\mathrm{R}^{2}$ of 0.8516 . Multiple regression analysis of the experimental data gave the following second-order 


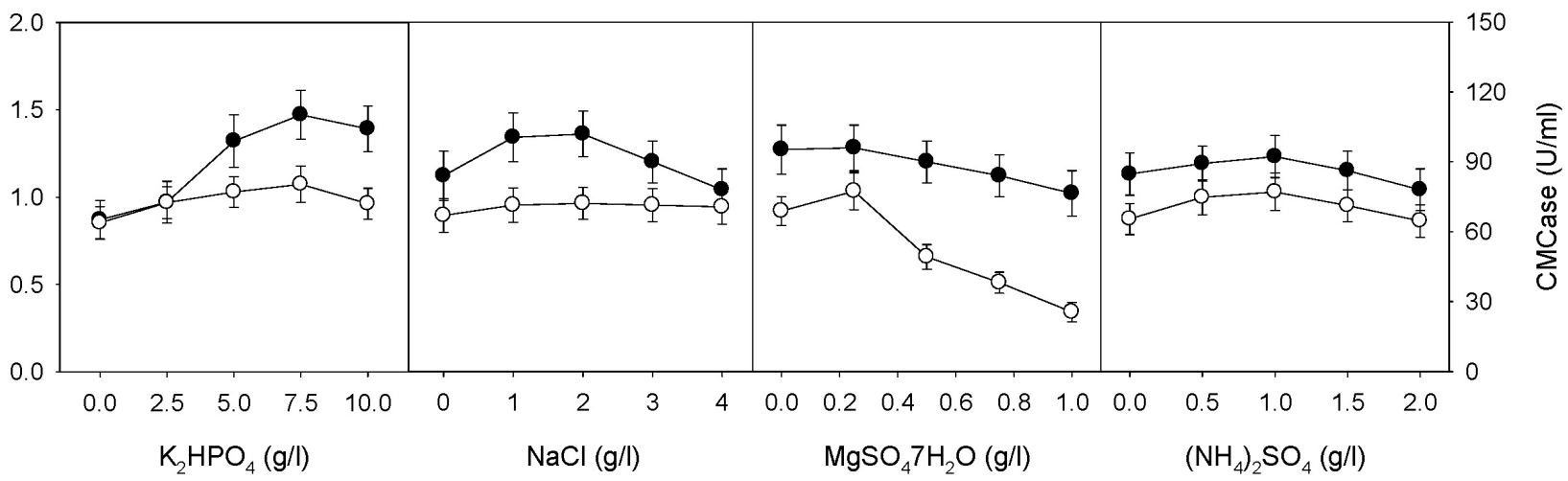

Fig. 5. Effect of salts in the medium on cell growth and production of CMCase by B. velezenssis A-68. $\mathbf{0}, \mathrm{DCW}$ and $\bigcirc, \mathrm{CMCase}$

Table 4. Central composite design (CCD) for optimization of four salts in medium and determined response values

\begin{tabular}{|c|c|c|c|c|c|c|}
\hline Run & $X_{1}$ & $X_{2}$ & $X_{3}$ & $X_{4}$ & $\mathrm{Y}_{1}(\mathrm{~g} / \mathrm{l})$ & $\mathrm{Y}_{2}(\mathrm{U} / \mathrm{ml})$ \\
\hline 1 & 2.5 & 3.0 & 0.1 & 0.3 & 1.15 & 75.0 \\
\hline 2 & 5.0 & 2.0 & 0.2 & 0.6 & 1.28 & 76.8 \\
\hline 3 & 5.0 & 2.0 & 0.0 & 0.6 & 1.28 & 75.7 \\
\hline 4 & 5.0 & 0.0 & 0.2 & 0.6 & 1.22 & 75.5 \\
\hline 5 & 7.5 & 3.0 & 0.3 & 0.9 & 132 & 75.4 \\
\hline 6 & 10.0 & 2.0 & 0.2 & 0.6 & 1.35 & 75.5 \\
\hline 7 & 7.5 & 1.0 & 0.3 & 0.3 & 1.31 & 73.4 \\
\hline 8 & 0.0 & 2.0 & 0.2 & 0.6 & 1.17 & 73.5 \\
\hline 9 & 2.5 & 1.0 & 0.1 & 0.9 & 1.24 & 77.0 \\
\hline 10 & 7.5 & 3.0 & 0.3 & 0.3 & 1.27 & 73.4 \\
\hline 11 & 5.0 & 2.0 & 0.2 & 0.6 & 1.24 & 75.9 \\
\hline 12 & 5.0 & 2.0 & 0.2 & 0.0 & 1.28 & 74.0 \\
\hline 13 & 5.0 & 4.0 & 0.2 & 0.6 & 1.20 & 76.4 \\
\hline 14 & 2.5 & 3.0 & 0.3 & 0.9 & 1.20 & 73.4 \\
\hline 15 & 2.5 & 3.0 & 0.1 & 0.9 & 1.20 & 77.0 \\
\hline 16 & 5.0 & 2.0 & 0.2 & 0.6 & 1.33 & 77.3 \\
\hline 17 & 2.5 & 1.0 & 0.1 & 0.3 & 1.19 & 75.0 \\
\hline 18 & 5.0 & 2.0 & 0.2 & 0.6 & 1.30 & 77.5 \\
\hline 19 & 5.0 & 2.0 & 0.2 & 0.6 & 1.27 & 76.2 \\
\hline 20 & 7.5 & 1.0 & 0.1 & 0.3 & 1.31 & 77.0 \\
\hline 21 & 7.5 & 1.0 & 0.1 & 0.9 & 1.36 & 79.0 \\
\hline 22 & 7.5 & 1.0 & 0.3 & 0.9 & 1.36 & 75.4 \\
\hline 23 & 5.0 & 2.0 & 0.4 & 0.6 & 1.27 & 71.1 \\
\hline 24 & 2.5 & 3.0 & 0.3 & 0.3 & 1.15 & 71.4 \\
\hline 25 & 7.5 & 3.0 & 0.1 & 0.3 & 1.28 & 77.0 \\
\hline 26 & 7.5 & 3.0 & 0.1 & 0.9 & 1.33 & 79.0 \\
\hline 27 & 5.0 & 2.0 & 0.2 & 1.2 & 1.35 & 76.4 \\
\hline 28 & 2.5 & 1.0 & 0.3 & 0.3 & 1.18 & 71.4 \\
\hline 29 & 2.5 & 1.0 & 0.3 & 0.9 & 1.23 & 73.4 \\
\hline 30 & 5.0 & 2.0 & 0.2 & 0.6 & 1.25 & 76.5 \\
\hline
\end{tabular}

polynomial equation in terms of coded factors (Eq. 6) and the optimal concentrations of $\mathrm{K}_{2} \mathrm{HPO}_{4}, \mathrm{NaCl}, \mathrm{MgSO}_{4} \cdot 7 \mathrm{H} 2 \mathrm{O}$, and $\left(\mathrm{NH}_{4}\right)_{2} \mathrm{SO}_{4}$ for cell growth were $7.50,1.00,0.10$, and 0.80 $\mathrm{g} / \mathrm{l}$, respectively. The maximum cell growth of $1.35 \mathrm{~g} / 1$ was predicted by the model. The maximal actual value of cell growth was $1.36 \mathrm{~g} / 1$ when concentrations of $\mathrm{K}_{2} \mathrm{HPO}_{4}, \mathrm{NaCl}$, $\mathrm{MgSO}_{4} \cdot 7 \mathrm{H}_{2} \mathrm{O}$, and $\left(\mathrm{NH}_{4}\right)_{2} \mathrm{SO}_{4}$ were $7.5,1.0,0.1$, and $0.9 \mathrm{~g} / \mathrm{l}$, respectively.

$Y_{1}=5.33+0.03 X_{1}+0.03 X_{3}+0.04 X_{4}+0.01 X_{1} X_{3}+0.01 X_{2} X_{3}-0.01 X_{2}$ 


$$
X_{4}+0.01 X_{3} X_{4}+0.02 X_{1}^{2}+0.01 X_{2}^{2}+0.01 X_{3}^{2}+0.01 X_{4}^{2}
$$

The ANOVA of the production of CMCase by B. velezensis A-68 indicated that this model and the model terms of $X_{1}$, $\mathrm{X}_{3}, \mathrm{X}_{4}$, and $\mathrm{X}_{3}{ }^{2}$ were highly significant and that of $\mathrm{X}_{3}{ }^{2}$ was significant for cell growth. The model $F$-value of 16.07 also implied that this model was significant. The regression equation obtained from the ANOVA indicated that the multiple correlation coefficient of $R^{2}$ was 0.9375 . The value of the adjusted determination coefficient (Adj. $R^{2}=0.8792$ ) was very high to advocate for a high significance of this model. Multiple regression analysis of the experimental data gave the following second-order polynomial equation in terms of coded factors (Eq. 7) and the optimal concentrations of $\mathrm{K}_{2} \mathrm{HPO}_{4}, \mathrm{NaCl}, \mathrm{MgSO}_{4} \cdot 7 \mathrm{H}_{2} \mathrm{O}$, and $\left(\mathrm{NH}_{4}\right)_{2} \mathrm{SO}_{4}$ for cell growth were $7.50,1.00,0.10$, and $0.80 \mathrm{~g} / \mathrm{l}$, respectively. The maximum production of CMCase of $78.3 \mathrm{U} / \mathrm{ml}$ was predicted by the model. The maximal actual value of CMCase production was $79.0 \mathrm{U} / \mathrm{ml}$ when concentrations of $\mathrm{K}_{2} \mathrm{HPO}_{4}$, $\mathrm{NaCl}, \mathrm{MgSO}_{4} \cdot 7 \mathrm{H}_{2} \mathrm{O}$, and $\left(\mathrm{NH}_{4}\right)_{2} \mathrm{SO}_{4}$ were $7.5,3.0,0.1$, and $0.9 \mathrm{~g} / \mathrm{l}$, respectively.

$$
\begin{aligned}
Y_{2} & =76.70+0.83 X_{1}+0.08 X_{2}-1.58 X_{3}+0.87 X_{4}-0.48 X_{1}^{2}-0.11 X_{2}^{2} \\
& -0.75 X_{3}^{2}-0.30 X_{4}^{2}
\end{aligned}
$$

Many studies including types of strains, culture conditions, and substrates on production of cellulases have been reported $[9,13,19]$. However, there have been few reports on optimization of mineral salts in the medium on production of cellulases [15]. Results from RSM indicated that $\mathrm{K}_{2} \mathrm{HPO}_{4}$ was significant for cell growth of $B$. velezenssis A-68, whereas $\mathrm{K}_{2} \mathrm{HPO}_{4}, \mathrm{MgSO}_{4} \cdot 7 \mathrm{H}_{2} \mathrm{O}$, and $\left(\mathrm{NH}_{4}\right)_{2} \mathrm{SO}_{4}$ were significant for production of CMCase. Potassium phosphate is one of the major salts in the medium for productions of microbial polysaccharides and enzymes as well as a well-known ingredient in buffer solutions [8, 12, 21]. Sodium chloride was reported to be used as a physiological modulator of biosynthetic pathway of biopolymers [15]. Magnesium sulfate added to medium assist with spore germination and initial growth of $A$. fisheri, which results in 1.9 fold increased production of xylanase [28].

\section{Effect of temperature on production of CMCase}

The effect of temperature on cell growth and the production of CMCase by B. velezensis A-68 was investigated. The temperature for cell growth and production of CMC ranged from 25 to $45^{\circ} \mathrm{C}$. The carbon and nitrogen source and initial $\mathrm{pH}$ of the medium were $50.0 \mathrm{~g} / 1$ rice hulls, $5.00 \mathrm{~g} / 1$

Table 5. Parameter estimates and analysis of variance (ANOVA) of the design for optimization of four salts in medium for cell growth and production of CMCase by $B$. velezensis A-68

\begin{tabular}{ccccccc}
\hline & Source of variation & Degree of freedom & Sum of squares & Mean squares & $F$-value & Probe $>$ F \\
\hline & Model & 14 & 0.110 & 0.008 & 12.89 & $<0.0001$ \\
& $X_{1}$ & 1 & 0.077 & 0.077 & 130.13 & $<0.0001$ \\
& $X_{2}$ & 1 & 0.004 & 0.004 & 7.20 & 0.0170 \\
& $X_{3}$ & 1 & 0.000 & 0.000 & 0.25 & 0.6221 \\
& $X_{4}$ & 1 & 0.012 & 0.012 & 20.52 & 0.0004 \\
& $X_{1}^{2}$ & 1 & 0.001 & 0.001 & 1.81 & 0.1986 \\
& $X_{2}^{2}$ & 1 & 0.010 & 0.010 & 16.28 & 0.0011 \\
& $X_{3}^{2}$ & 1 & 0.000 & 0.000 & 0.29 & 0.5985 \\
& $X_{4}^{2}$ & 1 & 0.002 & 0.002 & 2.61 & 0.1273 \\
& Error growth & 5 & 0.005 & 0.001 & - & - \\
& Total & 29 & 0.120 & - & - & - \\
\hline & Model & 14 & 115.050 & 8.220 & 16.07 & $<0.0001$ \\
& $X_{1}$ & 1 & 16.670 & 16.670 & 32.59 & $<0.0001$ \\
& $X_{2}$ & 1 & 0.140 & 0.140 & 0.26 & 0.6149 \\
& $X_{3}$ & 1 & 60.170 & 60.170 & 117.65 & $<0.0001$ \\
& $X_{4}$ & 1 & 18.030 & 18.030 & 35.25 & $<0.0001$ \\
& $X_{1}^{2}$ & 1 & 6.240 & 6.240 & 6.24 & 0.0033 \\
& $X_{2}^{2}$ & 1 & 0.360 & 0.360 & 0.36 & 0.4146 \\
& $X_{3}^{2}$ & 1 & 15.510 & 15.510 & 15.51 & $<0.0001$ \\
& $X_{4}^{2}$ & 1 & 2.500 & 2.500 & 2.50 & 0.0429
\end{tabular}


yeast extract, and $\mathrm{pH} 7.30$, respectively. The optimal temperatures for cell growth and the production of CMCase by $B$. velezensis A-68 were found to be 30 and $35^{\circ} \mathrm{C}$, respectively, as shown in Fig. 6. Cell growth and the production of CMCase by $B$. velezensis A-68 under optimized conditions were $1.38 \mathrm{~g} / 1$ and $83.8 \mathrm{U} / \mathrm{ml}$.

The optimal temperatures for cell growth and the production of CMCase by B. subtilis subsp. subtilis A-53 were 35 and $30^{\circ} \mathrm{C}$, respectively [19]. The optimal temperatures for production of CMCases ranged from 25 to $37^{\circ} \mathrm{C}$, except for thermophilic microorganisms such as Thermoascus aurantiacu, which optimal temperature for the production of CMCase is $50^{\circ} \mathrm{C}$ [10]. The optimal temperature for cell growth of $B$. amyloliquefaciens DL-3 was $32^{\circ} \mathrm{C}$, whereas that for production of CMCase was $37^{\circ} \mathrm{C}$ [9]. The optimal temperature for cell growth of $B$. velezensis A-68 was also different from that for production of CMCase as production of other CMCases.

Mass production of CMCase under optimized conditions in a 100 I bioreactor

Batch culture for the production of CMCase by B. velezensis A-68 was performed in a 1001 bioreactor under optimized conditions in this study. Carbon and nitrogen source was $50.0 \mathrm{~g} / 1$ rice hulls and $5.0 \mathrm{~g} / 1$ yeast extract. The initial $\mathrm{pH}$ and cultural temperature were 7.3 and $35^{\circ} \mathrm{C}$. Agitation speed and aeration rate of a 1001 bioreactor were $200 \mathrm{rpm}$ and $1.0 \mathrm{vvm}$. The $\mathrm{pH}$ in the medium dramatically decreased until $12 \mathrm{~h}$ of cultivation, and then gradually increased to approximately 7.5 thereafter, as shown in Fig. 7. Dissolved oxygen in the medium also dramatically decreased until 24 $\mathrm{h}$ and gradually increased after $36 \mathrm{~h}$. Cell growth of $B$. vele-

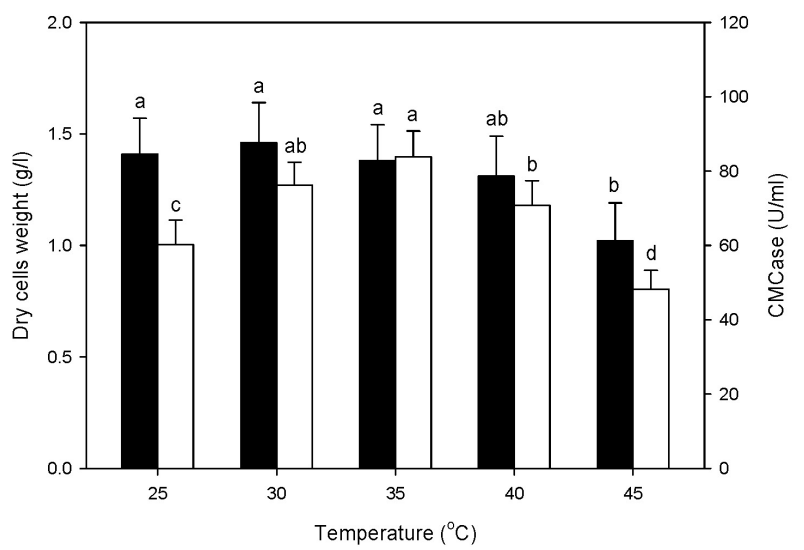

Fig. 6. Effect of temperature on cell growth and production of CMCase by B. velezensis A-68. $\square$, DCW and $\square$, CMCase zensis A-68 rapidly increased until $36 \mathrm{~h}$. The production of CMCase by $B$. velezensis A- 68 appeared to be paralleled with cell growth. Production of CMCase by $B$. amyloliquefacience DL-3 had been reported to be paralleled with cell growth [9]. Production of cellulases by a psychrophilic marine bacterium, Psychrobacter aquimaris LBH-10 was also paralleled with cell growth [13]. The cell growth and production of CMCase in a 1001 bioreactor was $1.46 \mathrm{~g} / 1$ and $83.0 \mathrm{U} / \mathrm{ml}$.

In this study, rice hulls were developed as a substrate for the production of CMCase by a newly isolated marine bacterium, B. velezensis A-68. The optimal conditions for production of CMCase were established using response surface method, as show in Table 6 . The production of CMCase by $B$. velezensis A-68 in a 1001 bioreactor under optimized conditions established in the flask scale was almost the same as the maximal production of CMCase obtained in the flask scale, which meant that the optimized conditions in this study would be directly applied for mass production of CMCase in an industrial scale $[5,20]$. Time for production of cellulases by fungal species in solid-state fermentation normally takes 7 to 10 days [11]. However, the time for production of CMCase by $B$. velezensis A- 68 reduced to 3 days in suspension culture. The optimal conditions for production of CMCase by bacterial and fungal species were compared, as shown in Table 7. The productivities of CMCase by recombinant strains were normally higher than those by wild types. Next study will be focused on construction of recombinant strains and characterization of their CMCases with an expectation of distinctive features such as cold-adapted, halo-tolerant or acidophilic CMCase due to its living in severe conditions and

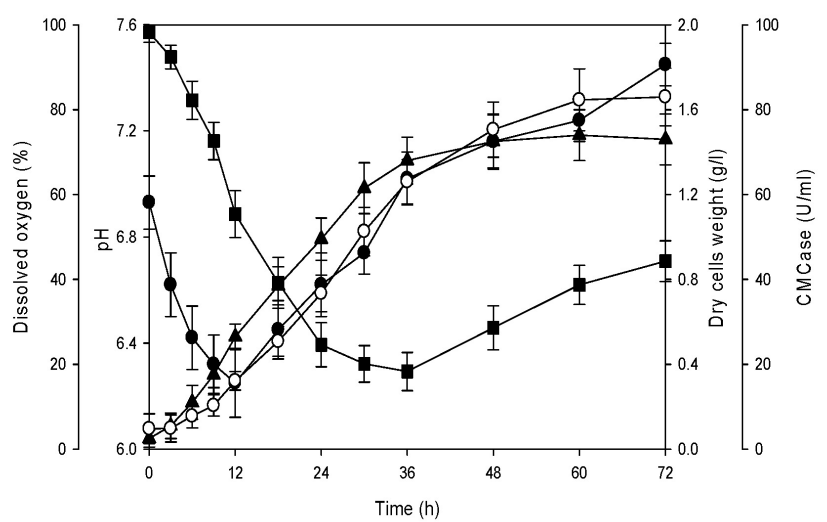

Fig. 7. Pilot-scaled production of CMCase by $B$. velezensis A-68 in a $100 \mathrm{~L}$ bioreactor. $\mathrm{O}, \mathrm{pH} ; \mathbf{\square}, \mathrm{DO} ; \mathbf{\Lambda}, \mathrm{DCW}$; and $\mathrm{O}, \mathrm{CMCase}$ 
Table 6. Optimal conditions for cell growth and production of CMCase by B. velezensis A-68

\begin{tabular}{|c|c|c|c|c|c|c|c|}
\hline \multirow{4}{*}{ Scale } & \multirow{4}{*}{ Condition } & \multicolumn{6}{|c|}{ Optimal conditions } \\
\hline & & \multirow{2}{*}{\multicolumn{2}{|c|}{$\begin{array}{l}\text { One-factor-at-a-time } \\
\text { experiment }\end{array}$}} & \multicolumn{4}{|c|}{ Response surface method } \\
\hline & & & & \multicolumn{2}{|c|}{ Predicted value } & \multicolumn{2}{|c|}{ Actual value } \\
\hline & & DCW & CMCase & DCW & CMCase & DCW & CMCase \\
\hline \multirow{4}{*}{ Flask scale-1 } & Rice hulls (g/l) & 50.0 & 50.0 & 60.2 & 50.0 & 50.0 & 50.0 \\
\hline & Yeast extract $(\mathrm{g} / \mathrm{l})$ & 7.5 & 5.0 & 7.38 & 5.00 & 5.0 & 5.0 \\
\hline & Initial $\mathrm{pH}$ & 7.3 & 7.3 & 7.18 & 7.30 & 7.3 & 7.3 \\
\hline & Maximal production & $1.24 \mathrm{~g} / 1$ & $62.0 \mathrm{U} / \mathrm{ml}$ & $1.23 \mathrm{~g} / 1$ & $61.3 \mathrm{U} / \mathrm{ml}$ & $1.22 \mathrm{~g} / 1$ & $61.7 \mathrm{U} / \mathrm{ml}$ \\
\hline \multirow{5}{*}{ Flask scale-2 } & $\mathrm{K}_{2} \mathrm{HPO}_{4}(\mathrm{~g} / \mathrm{l})$ & 7.5 & 7.5 & 7.50 & 7.50 & 7.5 & 7.5 \\
\hline & $\mathrm{NaCl}(\mathrm{g} / \mathrm{l})$ & 2.0 & 2.0 & 1.00 & 1.00 & 1.0 & 3.0 \\
\hline & $\mathrm{MgSO}_{4} \cdot 7 \mathrm{H}_{2} \mathrm{O}(\mathrm{g} / \mathrm{l})$ & 0.25 & 0.25 & 0.10 & 0.10 & 0.1 & 0.1 \\
\hline & $\left(\mathrm{NH}_{4}\right)_{2} \mathrm{SO}_{4}(\mathrm{~g} / \mathrm{l})$ & 1.0 & 1.0 & 0.80 & 0.80 & 0.9 & 0.9 \\
\hline & Maximal production & $1.34 \mathrm{~g} / 1$ & $76.8 \mathrm{U} / \mathrm{ml}$ & $1.35 \mathrm{~g} / 1$ & $78.3 \mathrm{U} / \mathrm{ml}$ & $1.36 \mathrm{~g} / 1$ & $79.0 \mathrm{U} / \mathrm{ml}$ \\
\hline \multirow{2}{*}{ Flask scale-3 } & Temperature $\left({ }^{\circ} \mathrm{C}\right)$ & 30 & 35 & - & - & - & - \\
\hline & Maximal production & $1.46 \mathrm{~g} / 1$ & $83.8 \mathrm{U} / \mathrm{ml}$ & - & - & - & - \\
\hline
\end{tabular}

Table 7. Comparison of optimal conditions for the production of various CMCases by bacterial and fungal microorganisms

\begin{tabular}{|c|c|c|c|c|c|c|}
\hline Strain & Carbon source & Nitrogen source & $\begin{array}{c}\text { Initial } \\
\mathrm{pH}\end{array}$ & $\begin{array}{c}\text { Temperature } \\
\left({ }^{\circ} \mathrm{C}\right)\end{array}$ & Productivity & Reference \\
\hline Bacillus amyloliquefaciens DL-3 & Rice hulls & Peptone & 6.8 & 37 & $367 \mathrm{U} / \mathrm{ml}$ & [9] \\
\hline Bacillus atrophaeus LBH-18 & Rice bran & peptone & 7.0 & 30 & $128 \mathrm{U} / \mathrm{ml}$ & [17] \\
\hline Bacillus licheniformis LBH-52 & Rice hulls & Ammonium nitrate & 7.0 & 36 & $75 \mathrm{U} / \mathrm{ml}$ & [13] \\
\hline Bacillus subtilus subsp. subtilis A-53 & Rice bran & Yeast extract & 6.8 & 30 & $137 \mathrm{U} / \mathrm{ml}$ & [19] \\
\hline Bacillus velezensis A-68 & Rice hulls & Yeast extract & 7.3 & 35 & $84 \mathrm{U} / \mathrm{ml}$ & This study \\
\hline Cellulophaga lytica LBH-14 & Rice bran & Ammonium chloride & 6.1 & 25 & $154 \mathrm{U} / \mathrm{ml}$ & [5] \\
\hline Psychrobacter aquimaris $\mathrm{LBH}-10$ & Rice bran & peptone & 8.0 & 30 & $339 \mathrm{U} / \mathrm{ml}$ & [14] \\
\hline Escherichia coli JM109/DL-3 & Rice bran & Peptone & 7.2 & 37 & $871 \mathrm{U} / \mathrm{ml}$ & [22] \\
\hline Escherichia coli JM109/A-53 & Rice bran & Ammonium chloride & 8.0 & 35 & $880 \mathrm{U} / \mathrm{ml}$ & [20] \\
\hline Aspergillus niger $\mathrm{KK} 2$ & Rice straw & Yeast extract & 7.0 & 28 & $129 \mathrm{U} / \mathrm{g} \mathrm{CS}^{\mathrm{a}}$ & [11] \\
\hline
\end{tabular}

a carbon source

wide ranges of environments [6].

\section{Acknowledgement}

This research was financially supported by the Ministry of Education, Science Technology (MEST) and National Research Foundation of Korea (NRF) through the Human Resource Training Project for Regional Innovation.

\section{References}

1. Blumer-Schuette, S. E., Kataeva, I., Westpheling, J., Adams, M. W. W. and Kelly, R. M. 2008. Extremely thermophilic microorganisms for biomass conversion: status and prospects. Curr Opin Biotechnol 19, 210-217.

2. Chun, J. 1995 Computer-assisted classification and identification of actinomycestes. Ph D Thesis, University of Newcastle, Newcastle upon Tyne, UK.
3. Chun, J. and Bae, K. S. 2000. Phylogenetic analysis of Bacillus subtilis and related taxa based on partial gyrA gene sequence. Antonie van Leeuwenhoek 78, 123-127.

4. Gao, W., Lee, E. J., Lee, S. U., Li, J., Chung, C. H. and Lee, J. W. 2012. Enhanced carboxymethylcellulase production by a newly isolated marine bacterium, Cellulophaga lytica LBH-14, using rice bran. J Microbid Biotechnol 22, 1415-1425.

5. Gao, W., Lee, S. U., Li, J. and Lee, J. W. 2013. Enhanced production of carboxymethylcellulase by Cellulophaga lytica LBH-14 in pilot-scale bioreactor under optimized conditions involved in dissolved oxygen. Korean J Chem Eng 30, 1105-1110.

6. Irwin, J. A., Alfredsson, G. A., Lanzetti, A. J., Gudmundsson, H. M. and Engel, P. C. 2001. Purification and characterization of a serine peptidase from the marine psychrophile strain PA-43. FEMS Microbiol 201, 285-290.

7. Jecu, L. 2000. Solid state fermentation of agricultural wastes for endogulcanse production. Ind Crop Prod 11, 1-5.

8. Jin, I. H., Jung, D. Y., Son, C. W., Kim, S. K., Gao, W., Chung, C. H. and Lee, J. W. 2011. Enhanced production of hetero- 
polysaccharide-7 by Beijerinkia indica HS-2001 in repeated batch culture with optimized substitution of culture medium. Biotechnol Bioproces Eng 16, 245-255.

9. Jo, K. I., Lee, Y. J., Kim, B. K., Lee, B. H., Chung, C. H., Nam, S. W., Kim, S. K. and Lee, J. W. 2008. Pilot-scale production of carboxymethylcellulase from rice hull by Bacillus amyloliquefaciens DL-3. Biotechnol Bioprocess Eng 13, 182-188.

10. Kalogeris, E., Christakopoulos, P., Katapodis, P., Alexious, A., Vlachou, S., Kekos, D. and Macris, B. J. 2003. Production and characterization of cellulolytic enzymes from the thermophilic fungus Thermoascus aurantiacus under solid state cultivation of agricultural waste. Process Biochem 38, 1099-1104.

11. Kang, S. W., Park, Y. S., Lee, J. S., Hong, S. I. and Kim, S. W. 2004. Production of cellulase and hemicellulases by Aspergillus niger KK2 from lignocellulosic biomass. Bioresour Technol 91, 153-156.

12. Kim, B. K., Lee, B. H., Lee, Y. J., Jin, I. H., Chung, C. H. and Lee, J. W. 2009. Purification and characterization of carboxymethylcellulase isolated from a marine bacterium, Bacillulus subsp. subtilis A-53. Enzyme Microb Technol 44, 411-416.

13. Kim, H. J., Gao, W., Chung, C. H. and Lee, J. W. 2011. Statistical optimization for production of carboxymethylcellulase from rice hulls by a new isolated marine microorganism Bacillus licheniformis LBH-52 using response surface method. J Life Sci 21, 1083-1093.

14. Kim, H. J., Gao, W., Lee, Y. J., Chung, C. H. and Lee, J. W. 2010. Characterization of acidic carboxymethylcellulase produced by a marine microorganism, Psychrobacter aquimaris LBH-10. J Life Sci 20, 487-495.

15. Kim, H. J., Lee, Y. J. Gao, W., Chung, C. H., and Lee, J. W. 2012. Optimization of salts in medium for production of carboxymethylcellulase by a psychrophilic marine bacterium, Psychrobacter aquimaris LBH-10 using two statistical methods. Korean J Chem Eng 29, 384-391.

16. Kim, H. J., Lee, Y. J., Gao, W., Chung, C. H., Son, C. W. and Lee, J. W. 2011. Statistical optimization of fermentation conditions and comparison of their influences on production of cellulases by Psychrophilic marine bacterium, Psychrobacter aquimaris LBH-10 using orthogonal array method. Biotechnol Bioprocess Eng 16, 542-548.

17. Kim, Y. J., Gao, W., Lee, S. U., and Lee, J. W. 2012. Enhanced production of carboxymethylcellulase by a newly isolated marine microorganism Bacillus atrophaeus LBH-18 using rice bran, a byproduct from the rice processing industry. J Life Sci 22, 1295-1306.

18. Kumar, S., Tamura, K. and Nei, N. 1993. MEGA N. Molecular evolutionary genetic analysis, version 1.01, The Pennsylvania State University, University Park. USA.

19. Lee, B. H., Kim, B. K., Lee, Y. J., Chung, C. H. and Lee, J. W. 2010. Industrial scale of optimization for the production of carboxymethylcellulase from rice bran by a marine bacterium, Bacillulus subsp. subtilis A-53. Enzyme Microb Technol 46, 38-42.

20. Lee, E. J., Lee, B. H., Kim, B. K. and Lee, J. W. 2013.
Enhanced production of carboxymethylcellulase of a marine microorganism, Bacillus subtilis subsp. subtilis A-53 in a pilot-scaled bioreactor by a recombinant Escherichia coli JM109/A-53 from rice bran. Mol Biol Rep 40, 3609-3621.

21. Lee, N. K., Jo, Y. B., Jin, I. H., Son, C. W. and Lee, J. W. 2009. The effect of potassium phosphate as a $\mathrm{pH}$ stabilizer on the production of gellan by Sphingomonas paucibilis Nk-2000. J Life Sci 19, 1033-1038.

22. Lee, Y. J., Kim, H. J., Gao, W., Chung, C. H., and Lee, J. W. 2012. Statistical optimimization for production of carboxymethylcellulase of Bacillus amyloliquefaciens DL-3 by a recombinant Escherichia coli JM109/DL-3 from rice bran using response surface method. Biotechnol Bioprocess Eng 17, 227-235.

23. Liu, J., Zhang, Z., Liu, Z., Zhu, H., Dang, H., Lu, J. and Cui, Z. 2011. Production of cold-adapted amylase by marine bacterium Wangia sp. 53: optimization, modeling, and partial characterization. Mar Biotechnol 13, 837-844.

24. MercoPress 2011. Global rice production reaches 476 million tons in 2011; strong Mercosur recovery. South Atlantic News Agency, June $27^{\text {th }}$, USA.

25. Park, E. Y., Ikeda, Y. and Okuda, N. 2002. Empirical evaluation of cellulose on enzymatic hydrolysis of waste office paper. Biotechnol Bioprocess Eng 7, 268-274.

26. Roboson, L. M. and Chambliss, G. H. 1989. Cellulases of bacterial origin. Enzyme Microb Technol 11, 626-644.

27. Saha, B. C. and Cotta, M. A. 2008. Lime pretreatment, enzymatic saccharification and fermentation of rice hulls to ethanol. Biomass Bioenergy 32, 971-977.

28. Senthikumar, S. R., Ashokkumar, A., Raj, K. C. and Cunasekraran, P. 2005. Optimization of medium composition for alkali-stable xylanase production by Aspergillus fischeri Fxn 1 in solid-state fermentation using central composite rotary desing. Bioresour Technol 96, 1380-1386.

29. Sukumaran, R. K., Singhania, R. R., Mathew, G. M. and Pandey, A. 2009. Cellulase production using biomass feed stock and its application in lignocellulose saccharification for bio-ethanol production. Renew Energy 34, 421-424.

30. Suzuki, T., Yamamoto, K., Tada, H. and Uda, K. 2012. Cold-adapted features of arginine kinase from the deep-sea clam Calyptogena kaikoi. Mar Biotechnol 13, 294-303.

31. Takagi, M., Abe, S., Suzuki, S., Emert, G. H. and Yata, N. 1977. A method for production of ethanol directly from cellulose using cellulase and yeast. Ghose, T. K. (ed), Proceedings of Bioconversion Symposium, Dheli, India.

32. Thompson, J. D., Higgins, D. G. and Gibson, T. J. 1994. CLUSTAL W. Improving the sensitivity of progressive multiple sequence alignment through sequence weighting, positions-specific gap penalties and weight matrix choice Nucleic Acids Res 22, 4673-4680.

33. Wei, G. Y., Lee, Y. J., Kim, Y. J., Jin, I. H., Lee, J. H., Chung, C. H. and Lee, J. W. 2010. Kinetic study on the pretreatment and enzymatic saccharification of rice hull for the production of fermentable sugars. Appl Biochem Biotechnol 162, 1471-1482. 
초록 : 통계학적 방법을 사용한 해양미생물 Bacillus velezensis A-68균주의 섬유소 분해효소 생산 조건 최적화

\section{김보경 $\cdot$ 김혜진 ${ }^{2} \cdot$ 이진우 ${ }^{2} *$}

('한국바이오솔루션, ${ }^{2}$ 동아대학교 생명공학과)

섬유소 분해효소(carbxymethylcellulase)를 생산하는 미생물을 해수에서 분리하여 16S rDNA 및 gyrase 유전자의 염 기서열을 분석하여 동정한 결과, Bcaillus velezensis로 확인되었으며 B. velezensis A-68로 명명하였다. 이 균주가 생산하는 섬유소 분해효소의 생산 조건을 최적화하기 위하여 통계학적 방법인 response surface method (RSM)를 사용하였다. 이 균주의 생육에 최적인 왕겨, 효모 추출물 및 배지의 초기 $\mathrm{pH}$ 는 $60.2 \mathrm{~g} / \mathrm{l}, 7.38 \mathrm{~g} / 1$ 및 7.18이었으나, 섬유소 분해효소 생산에 최적인 왕겨, 효모 추출물 및 배지의 초기 $\mathrm{pH}$ 는 $50.0 \mathrm{~g} / \mathrm{l}, 5.99 \mathrm{~g} / 1$ 및 7.30이었다. 통계학적인 분석 결과, 균주의 생육 및 균주의 섬유소 분해효소 생산에 가장 큰 영향을 미치는 것은 효모 추출물이었다. 이 균주의 생육과 섬유소 분해 효소의 생산에 최적인 $\mathrm{K}_{2} \mathrm{HPO}_{4}, \mathrm{NaCl}, \mathrm{MgSO}_{4} \cdot 7 \mathrm{H}_{2} \mathrm{O}$ 및 $\left(\mathrm{NH}_{4}\right)_{2} \mathrm{SO}_{4}$ 의 농도는 각각 $7.50,1.00,0.10$, and $0.80 \mathrm{~g} / 1$ 이었다. 이 균주의 생육 및 섬유소 분해효소 생산에 최적인 온도는 각각 $30^{\circ} \mathrm{C}$ 및 $35^{\circ} \mathrm{C}$ 로 생육에 최적인 조건과 섬유소 분해효소 생산에 최적인 조건이 다름을 알 수 있었다. 이 균주가 생산하는 섬유소 분해효소의 생산성은 $83.8 \mathrm{~m} / 1$ 이며, 이는 최적 화하기 전의 생산성에 비하여 3.3 배 증가한 것이다. 이 연구를 통하여 농업 부산물인 왕겨를 섬유소 분해효소 생산을 위한 기질로 개발하였으며, 해수에서 분리한 미생물을 사용함으로써 섬유소 분해효소의 생산기간을 3 일로 단축할 수 있었다. 